\title{
The Effect of Earnings Opacity and Tax Avoidance on Companies Value
}

\author{
Adesia Gifara Sinekti ${ }^{1 \mathrm{a}}$, Made Dudy Satyawan ${ }^{1 \mathrm{~b} \bowtie}$ \\ ${ }^{\text {la,b) }}$ Accounting Departement, Faculty of Economics, Universitas Negeri Surabaya \\ Ketintang Street, Surabaya 60231, East Java, Indonesia
}

Email: madesatyawan@unesa.ac.id*, adesiasinekti@mhs.unesa.ac.id

\begin{abstract}
Companies in Indonesia have carried out many earnings modification practices where earnings modification is the attitude of management to choose accounting policy with various purposes or motives, namely opportunistic motives and efficiency motives. Opportunistic motive if the modification aims to provide welfare for management, while the efficient motive is if it aims to increase the market value of the company. This study functions to analyze the effect of earnings opacity, tax avoidance, price-earnings ratio, return on assets, and leverage on the value of food and beverage companies listed on the IDX in 2018-2020, with a sample of 15 companies based on the purposive sampling method. The research method used is quantitative. The results prove that earnings opacity and tax avoidance harms company value.
\end{abstract}

Keywords: Earnings opacity; Tax avoidance; The value of the companies

\begin{tabular}{l} 
Article History: Received: April 62021 Accepted: April 132021 Published: April 142021 \\
How to cite: Sinekti, A.G. \& Satyawan, M.D.(2021) The Effect of Earnings Opacity and Tax Avoidance \\
on Companies Value. Akrual: Jurnal Akuntansi $\quad$ (JA), 12(2): 230-242. \\
$\begin{array}{llll}\text { https://doi.org/10.26740/jaj.v12n2.p230-243 } & & & \end{array}$ \\
\hline
\end{tabular}

\section{INTRODUCTION}

Companies in Indonesia have carried out many earnings modification practices where earnings modification is the behavior of management to choose accounting procedures with various purposes or motives, namely opportunistic motives and efficiency motives. Opportunistic motive if the modification aims to provide welfare for the management, while the efficient motive is if it aims to increase the company's market value. Profit modification is often stated in various terms. Earnings opacity has been introduced by (Bhattacharya et al., 2017) who say that the level of information lost from accounting earnings in companies is due to earnings modifying which have a specific purpose. This is done by the agent, namely management who has a complete and valid level of information compared to the owner of the company so that this advantage is used by the agent to modify profits by maximizing the profits contained in the financial statements to get bonuses and promotions. The impact of high earnings opacity will affect the financial quality of the company by experiencing a decline in annual reports so that the financial statements are not in their true position. With this, it will be hampered in creating productivity of employee 
activities, acquisition of expertise, transfer of technology, and capital accumulation. It can be concluded that in modifying earnings, we must pay attention to the impact (Andriani, 2019).

Research on accounting earnings information on stock prices shows that the company's efforts to increase earnings have an impact on increasing stock prices (Ray Ball, 1968). An increase or decrease in company profits is accompanied by an increase or decrease in share prices. Announcement of accounting earnings has a very urgent function for an investor's decisions related to making investment decisions in companies, increasing in stock trading, and variability of stock returns in accounting profit.

According to research (Lasrya \& Ningsih, 2020), earnings opacity affects stock liquidity. Where the results show that the greater the value of discretionary accruals (proxy earnings opacity ), the higher the value of stock liquidity. This means that the lower the quality of the company's earnings, the lower the level of stock liquidity. Liquidity stock influencing the value of the company. Where stock liquidity is a reflection of company performance. Like investors who are interested in buying stocks, it means that the company's performance is good, which shows the high value of the company. According to (Bhattacharya et al., 2017) that earnings opacity in their research does not have a significant effect on a company's stock market. Interestingly, in this study, the results obtained show that the company's profit is only a history which does not indicate the company's prospects. So that investors in buying and selling shares do not refer to company profits, both modified profits and actual profits.

From the differences in the results of these studies until this study is to try again the effect of earnings opacity on firm value. Retesting the measurement tool of earnings opacity, namely using the absolute value of the performance adjusted discretionary accrual (ADA) which has been taken from the model (Kothari et al., 2005) which aims to regulate the company's performance factors that have been modified by Jones's model. An implementation of the model certainly encountered a weakness, and there is no doubt the Jones model that promotes changes in accounts receivable and changes in earnings as a term of discretionary accrual so that the model is improved on the model modified Jones's. The company's value can be used as a measuring tool is the reference company, and in comparing a company's stock price and the book value of equity used by Tobin's Q.

In addition to earnings opacity affecting firm value, taxes also affect firm value. Where tax avoidance is often done by prioritizing the interests of companies that are believed to be able to manage government assets in the form of taxes to companies and can increase company value. For (Wang et al., 2020) tax avoidance generally focuses on the potential impact of tax avoidance on companies and their shareholders. Other stakeholders are also able to respond to the behavior of tax evasion, for example, individual customers may prefer to buy products from companies they consider to pay a part of their fair share in taxes, which can be seen as a social responsibility. Business customers may prefer to partner with suppliers who engage in less risky corporate behavior, including less tax evasion, to ensure an uninterrupted supply of raw materials. 
Taxpayers take advantage of the ambiguous nature of the tax laws in tax storage. Shareholders have agreed that the existence of tax avoidance is tried by industry management when the benefits to be obtained from the compensation for service activities are greater than the budget issue. Taxes are also an aspect of ensuring the industry's decision-making. In the research results (Karimah \& Taufiq, 2016) that tax avoidance influences firm value. Activities Tax aggressiveness can increase and reduce the value of industrial shares. If the thought of tax aggressiveness as an effort to carry out tax planning and tax capabilities, so that the consequences can positively benefit company value. However, if observed through an act of disobedience, it can increase the risk of depreciation of the company value. Meanwhile, the research results according to (Fadillah, 2019) that there is no effect of tax avoidance on firm value. This can occur due to other activities that can affect company value.

Based on differences in results that have a tax avoidance effect on firm value, this study will be retested. This study is different from research (Fadillah, 2019), where the research has less complex deficiencies in the measuring instrument used by using the effective tax rate (ETR) measurement tool. In the use of this ETR measuring instrument, companies that have caused losses have not necessarily issued tax avoidance as well. So that the ETR is considered less precise. In this study, a better measuring tool is used, namely using the Boox Tax Different proxy, permanent difference, stated (He et al., 2020) where this measuring tool can strengthen the findings and results of the study. The subject of research used by the researchers is based on the manufacturing industry that is contained in the list on the Stock Exchange. With the presence of high competition and raw material prices are rapidly changing from time to time, it is possible as factors that affect the manufacturing industry to implement measures of earnings opacity or tax avoidance.

Manufacturing companies that have experienced several incidents in implementing tax evasion, namely PT. Coca Cola Indonesia. The phenomenon experienced by one of these wellknown companies is related to tax evasion in the amount of Rp.49.24 billion which was included in the national media, which was published in ko mpas.com in 2014. Furthermore, to fulfill legal rights the company filed an appeal to the government as a tax collector. This is related to the reasons or the basis that the company has fulfilled its obligations by the agreed rules. The problems associated with tax existed from 2002, 2003, 2004, and 2006. Based on the findings of the Directorate General of Taxes (DGT), especially in the finance department, which found a very large swelling that year. The high payment burden results in decreased taxable income so that the tax premium is also smaller. For the years 2002-2006, the company incurred fees related to very large promotions, which amounted to Rp. 566, 84 billion. That is for the promotion of beverage products from the Coca-Cola brand.

The impact of this depreciation will directly and surely affect state income and of course, harm the state. The government's efforts to tackle fraud committed by companies to order to avoid paying taxes are considered effective. The activities carried out by one of these companies 
that are detrimental to state revenues are proof that the company has deliberately avoided paying taxes. The company wants to make a large profit but also wants to avoid paying large taxes from the government. There is a tendency for companies in the taxpayer regulations to try legally and illegally to reduce the taxes that will be paid to the government. This behavior that can be the cause of tax resistance against tax avoidance, then also becomes a potential basis for this (Murkana \& Putra, 2020). The research subjects used a food and beverage company listed on the IDX in a predetermined period of 2018-2020 to publish their financial statements. Sourced from the description above, until this research is entitled "Effect of Earnings Opacity and Tax Avoidance on Companies Value".

\section{RESEARCH METHOD}

\section{Types of Research and Data Sources}

This research uses quantitative research methods, where the data is in digital form or calculated through statistical calculations. Quantitative methods are more focused on symptoms or phenomena that are clear, specific, observable, measurable, and causal (Sugiyono, 2011 ). Determine the relationship using this type of explanatory research clause and through testing between variables. In this research, secondary information is used, namely financial reports and annual reports which are taken on the IDX with the website ( www.IDX.co.id ). Data sources were taken in the period 2018 to 2020.

\section{Population and Sample}

The population is a set of complete elements that can be people, objects, transactions, or events, all of which are interesting for research (Kuncoro, 2013: 145). The population of this study is the food and beverage sector. The food and beverage industry is an industry that plays an important role in the Indonesian economy. In research uses a method purposive sampling criteria company in the sectors of food and beverage listed on the Stock Exchange by issuing financial reports continuously in 2018 to 2020 and annual reports starting in 2018 to 2020. The overall sample in this study was 15 samples.

\section{Variables and Operational Definitions \\ Earnings Opacity}

Earnings opacity, a measure of the distribution of earnings that is reported to fail to provide correct earnings information. If the profit becomes more opaque, the signal of changes in economic value that occurred during the period provided by the reported accounting profit is increasingly imprecise. In this study, using the accrual discretion in the Modified Jones model.

Information:

$$
\mathrm{TACC}_{\mathrm{it}}=\alpha_{0}+\alpha_{1}\left(\Delta R E V_{i t}-\Delta A R_{i t}\right)+\alpha_{2} P P E_{i t}+\varepsilon_{i t}
$$

TACC $_{\text {it }}=$ Total accrual at the company $\mathrm{i}$ year $\mathrm{t}$ is the difference between earnings and cash flow originating from operating cash flow activities divided by total assets in the company $i$ year $t$ 
$\triangle R E V_{i t} \quad=$ Change in income divided by total asests of the company $\mathrm{i}$ in year $\mathrm{t}$

$\triangle A R_{i t} \quad=$ Chane in trade receiveables divided by total assets in the company $\mathrm{i}$ in year $\mathrm{t}$

$P P E_{i t} \quad=$ The gross value of fix assets divided by total assets in the company $\mathrm{i}$ in year $\mathrm{t}$

\section{Tax Avoidance}

Tax avoidance is about the attempted create tax savings matched by the Act applicable to minimize the tax burden to maximize profits. In this study, a permanent difference in the company (DTAX) was used to measure tax avoidance by using residue $(\varepsilon)$ as an estimate of permanent discretionary differences (Frank et al., 2009).

$$
\text { PERMDIFF } i t=\alpha_{0}+\alpha_{1} I_{N T A N G}+\alpha_{2} U_{N C O N}+\alpha_{3} M_{i t}+\alpha_{4} \Delta N O L_{i t}+\alpha_{5} L_{A G P E R M_{i t}}+\varepsilon_{i t}
$$

\section{Information:}

PERMDIFF $_{\text {it }}=$ The total differences between commercial and taxable profits less temporary differences is divided bv total assets of the comnanv $i$ in vear $t$

INTANG $_{\text {it }} \quad=$ Goodwill and other intangible assets divided by the total assets of the company $\mathrm{i}$ in year $\mathrm{t}$

$\mathrm{UNCON}_{\mathrm{it}} \quad=$ Profit (loss) reported using the equity method divided by the total assets of the company $\mathrm{i}$ in year $\mathrm{t}$

$\mathrm{MI}_{\mathrm{it}} \quad=$ Profit (loss) borne by minority parties divided by the total assets of the company $\mathrm{i}$ in year $\mathrm{t}$

$\Delta \mathrm{NOL}_{\mathrm{it}}=$ Change in net operating loss that can be compensated divided by the total assets of company $\mathrm{i}$ in year $\mathrm{t}$

LAGPERM $_{i t} \quad=$ Lagged value of permanent difference divided by the total assets of company in in the year $\mathrm{t}$

$\varepsilon_{i t} \quad=$ Discretionary permanent difference $(\mathrm{DTAX})$ of company $\mathrm{i}$ in the year $\mathrm{t}$

\section{The value of the company}

Firm value is the benchmark for investors as the basis for their investment decisions associated with the stock price. The high value of the company results in a large level of welfare as a shareholder. In this study, the Tobins'Q measurement tool is used to equate industrial stock market figures with equity book numbers.

$$
\mathrm{Q}_{\mathrm{it}}=\left(\mathrm{EMV}_{\mathrm{it}}+\mathrm{D}_{\mathrm{it}}\right):\left(\mathrm{EBV} \mathrm{it}_{\mathrm{it}}+\mathrm{D}_{\mathrm{it}}\right)
$$

Qit $\quad=$ Firm value in the company I year $\mathrm{t}$

EMVit = Market value of equity in the company I year $t$

$\mathrm{EBVit}=$ Book value of total assets in the company I year $\mathrm{t}$

Dit $=$ Book value of total debt to the company I year $\mathrm{t}$ 


\section{Control Variable}

Control variables are controlling variables or are made constant, as a result, there is a result of the independent variable or independent variable on the limited variable which is not influenced by external aspects that are not carried out in the research. There are control variables that have where Price Earning Ratio (PER), Return on Assets (ROA), and leverage related to the value of the company.

\section{Price Earning Ratio (PER)}

PER is the ratio of share price to earnings per share, which represents the total paid by investors for each dollar of reported income (Brigham and Housten, 2011: 150). This means comparing the share price per share with earnings per share. For investors, a higher PER will lead to an increase in expected profit growth. The methods Brigham and Houston used in calculating PER were :

\section{Return On Assets (ROA)}

$$
\text { Price Earning Ratio }(\mathrm{PER})=(\text { Stock price }) /(\text { Earning Per Share }(\mathrm{EPS}))
$$

ROA is used to measure a company's ability to create profits starting from industrial investment activities (Irnawati, 2019). Capital invested in the industry is expected to be able to share profits with the assets owned. The ROA formula is:

$$
\text { Return On Assets }(\mathrm{ROA})=(\text { Net income after tax }) /(\text { Total assets })
$$

\section{Leverage}

Leverage is a comparison that describes the bond between loans and capital where the industry is the subject of measuring how much it uses debt or outsiders with industry expertise interpreted by capital (Fahmi, 2012: 75). The leverage formula is:

$$
\text { Leverage }=(\text { Total Debt }) /(\text { Total Capital }) \times 100 \%
$$

\section{Data Collection and Analysis Techniques}

In this study, data collection was carried out through financial reports and company annual reports using the food and beverage recording technology listed on the IDX for the period 2018 to 2020. The data that is then collected is the share price through the website. Then the data is processed using the SPSS 25 program. This research, it has been tried using multiple regression experiments to identify the bonds between related variables. This multiple regression procedure is one of the estimated tools that can meet the best Best Linear Unavailable Estimation (BLUE). Previous research used descriptive analysis as well as classical regression assumptions that included experiments for normality, multicollinearity, autocorrelation, and heteroscedasticity. Information analysis methods include the following:

\section{Multiple Linear Regression Analysis}

In this multiple linear regression model, testing the hypothesis equation as follows:

$$
\text { Qit }=\alpha 0+\alpha 1 \text { DACCit }+\alpha 2 \text { DTAXit }+\alpha 3 \text { LEVit }+\alpha 4 \text { PERit }+\alpha 5 \text { ROAit }+\varepsilon i t
$$




\section{RESULTS AND DISCUSSION}

\section{Multiple Linear Regression Analysis}

Multiple linear regression analysis is intended to see the effect of the independent variables Earnings Opacity, Tax Avoidance, PER, ROA, Leverage, and the dependent variable in the form of Firm Value. Multiple linear experimental results can be observed in the following table :

Table 1. Multiple Linear Regression Test Results

\begin{tabular}{lrrrl}
\hline \multicolumn{1}{c}{ Model } & $\begin{array}{c}\text { Regression } \\
\text { Coefficient }\end{array}$ & $\begin{array}{c}\text { Std. } \\
\text { Error }\end{array}$ & Sig. & Information \\
\hline (Constant) & 0.732 & 0.031 & 0.000 & \\
\hline Earnings_Opacity & -0.053 & 0.016 & 0.003 & Negative effect \\
\hline Tax_Avoidance & -0.032 & 0.009 & 0.001 & Negative effect \\
\hline PER & 4,581 & 0.000 & 0.043 & Positive effect \\
\hline ROA & -0.001 & 0.001 & 0.146 & Negative effect \\
\hline Leverage & -0.001 & 0.000 & 0.000 & Negative effect \\
\hline
\end{tabular}

a. Dependent Variable: Firm Value

Source: Processed primary data, 2021

Based on the results of multiple linear regression testing in the chart above to a mathematical form to measure the influence of the independent variables Earnings Opacity, Tax Avoidance, PER, ROA, Leverage and the dependent variable in the form of Company Value can be described as follows:

$$
\begin{gathered}
Y=\alpha+\beta_{1} X_{1}+\beta_{2} X_{2}+\beta_{3} X_{3}+\beta_{4} X_{4}+\beta_{5} X_{5}+\varepsilon \\
Y=0,732-0,053 X_{1}-0,032 X_{2}+4,581 X_{3}-0,001 X_{4}-0,001 X_{5}+0,031
\end{gathered}
$$

Information:

$\mathrm{Y} \quad=$ Firm Value

$\alpha \quad=$ Constanta

$\beta \quad=$ Coefficient

$\mathrm{X}_{1} \quad$ = Earning Opacity

$\mathrm{X}_{2}=$ Tax Avoidance

$\mathrm{X}_{3}=$ Price Earning Ratio

$\mathrm{X}_{4} \quad=$ Return on Asset

$\mathrm{X}_{5} \quad=$ Leverage

$\varepsilon \quad=$ Error

The regression equation above can be described as follows :

1) The constant is 0.732 ; means that if Earnings Opacity (X1), Tax Avoidance (X2), PER (X3), ROA (X4), and Leverage (X5) have some 0 until the firm value (Y) is estimated to be 0.732 or if the variable value the company is not influenced by other variables until the value is positive 0.732 . 
2) The regression coefficient of The Earnings Opacity (X1) is 0.053 ; That is, if the other independent variables are always in value and the Earnings Opacity variable faces an increase of $1 \%$, then the firm's value $(\mathrm{Y})$ is about to face a shrinkage of 0.053 . The coefficient of negative value means that there is a negative effect on earnings opacity on firm value, meaning that it continues to increase in earnings opacity until it continues to be a small value for the firm.

3) The tax avoidance variable regression coefficient (X2) is -0.032 , meaning that if the other independent variables have a fixed value and the tax avoidance variable increases by $1 \%$, the firm value (Y) will decrease by 0.032 . The negative coefficient indicates that tax avoidance harms firm value, meaning that the higher the level of tax avoidance, the lower the firm value.

4) Price Earning Ratio ( X3 ) variable regression coefficient of 4.581; This means that if the other independent variables are always in value and the PER variable faces an increase of $1 \%$ so that the firm's value (Y) is about to face an increase of 4.581 . The positive value coefficient means that there is a positive effect on PER to firm value, meaning that it continues to be a large PER until it continues to become the value of the company is also great.

5) The regression coefficient of the ROA variable ( $\mathrm{X} 4$ ) is -0.001 ; This means that if the other independent elastic values are always on and the ROA variable faces an increase of $1 \%$ so that the company value $(\mathrm{Y})$ is about to face a shrinkage of 0.001 . The minus value coefficient means that there is a negative effect on ROA on firm value, meaning that it continues to be a large ROA until it continues to become low firm value.

6) Leverage variable regression coefficient ( X5 ) of -0.001 ; This means that if the other independent variables are always in value and the Leverage variable faces an increase of $1 \%$ so that the firm value (Y) is about to face a shrinkage of 0.001 . The negative coefficient means that there is a negative effect on leverage on firm value, meaning that the higher the leverage, the lower the value. company.

7) The standard error value to minimize the errors that exist, the result is the value of e here is 0.031 .

\section{Effect of Earnings Opacity on Firm Value}

Based on the data analysis conducted by the researcher, it shows that the t value of the effect of income opacity on firm value is -3.388 , the P-value is 0.003 , and the coefficient (beta) is -0.053. Therefore it can be concluded that the profit opacity harms the industrial figures. The point is to continue to increase the opacity of the income of industrial administrators until the number of companies continues to be small; the opposite continues to be small, the opacity of the income of industrial managers so that the number of companies continues to increase.

Earnings opacity is a condition where reported earnings fail to provide information about the company's actual economic performance (Bhattacharya et al., 2017). According to agency theory, the information gap between managers and owners of capital is a major problem related to return opacity. Income opacity is performed using the accrual basis in the financial statements. This is because the accrual system is an element that can easily be adapted to the wishes or goals of the person operating. financial statement records. Earnings opacity is not a detrimental matter if the method of changing the value does not deviate from the financial reporting provisions in 
Financial Reporting Accounting Standard, namely, by processing discretionary accruals in financial statements. However, despite the earnings management behavior is not contrary to the principles that have been imposed are generally associated with it, but such behavior would have an impact on the quality of financial affect the quality of financial statements that led to increasing a company's value.

Regarding this, there is research that proves the existence of a positive influence carried out by managers on firm value in the food and beverage sector. Based on data obtained from 15 companies studied during the period 2018-2020, it can be seen that 8 companies have low and below average Qit values and 8 companies that have an earnings opacity value above average. From these studies can that earnings opacity that does managers in companies sub-sector food and beverage giving adverse reactions from the parties interested in the company. The bad reaction is caused because the earnings opacity action obscures information on the economic performance of the company and this action can mislead users of financial statements. When the objectives shared between the administrator and other parties concerned (investors, collectors, and similar) are different, then agency clashes cannot be avoided in the industry. The management wants to harm the owners of capital or shareholders by behaving incorrectly and intervening in the categorization of financial statements based on accrual accounting on the fundamental aspects of the company. An agency conflict that exists in an industry can have an impact on the quality of the profits earned, this is because managers want to play an opportunistic role. An opportunistic advantage would certainly be detrimental for some parties with low quality, not to replace the real data. That way, the earnings opacity that management tries to reduce the value of the company. The results of this research are in line with the research that was tried by (Lasrya \& Ningsih, 2020).

\section{The Effect of Tax Avoidance on Firm Value}

Referring to the conclusions of the analysis can be seen the value $t$ of influence tex evasion against the value of the company amounted to -3695 , the P-value amounted to 0.001 , and the coefficient $\beta$ of -0032. It can be concluded, for this study that tax avoidance harms firm value. In other words, the higher the level of tax avoidance carried out by company managers, the lower the company value, the opposite happens due to the lower the level of tax avoidance carried out by company managers, the higher the value of the company.

Tax avoidance is a tax-saving action that arises by using taxation determination that is tried legally to minimize the role of taxes (Karimah \& Taufiq, 2016). Action tax avoidance can be tried if the industry can minimize the importation or optimize the load guaranteed by the industry. Income tax expense is a deduction for industrial profits. As a result, if the weight guaranteed by the industry is large, tax avoidance can be tried and the tax that must be paid is small. It is in line with the agency philosophy, if the industry is required to share benefits to its stakeholders, the benefits given to industry stakeholders are in the form of large dividends. To get a large dividend, so that the tax payment must be kept as low as possible. However, the high weight guaranteed by the company can also undermine the value of the company. This is because industries that carry out tax avoidance often find negative thoughts by groups that take part in the responsibility of the company. 
The company has a reason for implementing the tax avoidance application, which is to reduce the tax debt that the industry wants to pay the next day. This is undoubtedly a description of the opportunistic attitude of managers who should share careful data with investors. The tax avoidance attitude can reflect the presence of individual managers needs with the method of fiscal rotten sense which causes incorrect data to existing this activity certainly shares an impact on shareholders which causes the shrinkage of the data content of the company's financial information, as a result, there will be potential for the formation of data asymmetry between industry and industry. the shareholders. This case shows that the market reacts negatively to the tax avoidance application that is being tried by the industry. These results are in line with the research tried by (Karimah \& Taufiq, 2016) and (Apsari \& Setiawan, 2018).

\section{The Influence of Price Earning Ratio (PER) on Firm Value}

According to the results of the analysis, it can be seen that PER has a value of 2.149 , a P value of 0.043 , and a coefficient (beta) of 4.581. Thus, it can be concluded that PER has a positive effect on industry figures. This means that the PER of the industry continues to be large so that the number of companies continues to be large, the opposite continues to be small, the PER of the industry continues to be small in company value.

The price-earning ratio is a comparison obtained by sorting the market price of a stock by the profit per share. Therefore, the price-earnings ratio (PER) can be used as a dimension to ascertain how the market assigns figures or prices to company shares. If the PER of the industry is large, it means that industrial stocks can share a large return for investors. Based on data obtained from 15 companies sub-sector of food and beverage throughout the year 2018sampai 2020, it can be concluded that seven corporate PER values above the average ideal company subsector of food and beverage and eight companies that have a value of earnings opacity above average. This is because a large PER can describe the price of industrial shares as large, an increase in stock price is intended to share capital gain, which is a factor of return, as a result, an increase in stock prices aims to increase the PER number, as well as increase the return on industrial shares.

The price earning ratio is a very meaningful aspect in terms of industrial finance, where if the PER of the industry is higher, there will be a greater chance for the industry to get a large return or rate of return. In this way, the market wants to react positively to industry figures because it shares thoughts that the industry is in fresh condition and proves the development of the company. Not only that, the PER share of a company continues to increase until the price per share is about to increase, as a result, the company wants to get profits that can increase the value of the company. These results are in line with the research tried by (Kushartono \& Nurhasanah, 2018).

\section{Effect of Return On Assets (ROA) on Firm Value}

This matter can be observed from the results of the analysis if the number $t$, the effect of ROA on the firm value is -1.507 , the $\mathrm{P}$-value is 0.146 , and the $\beta$ coefficient is -0.001 . Thus it can be concluded that the rate of return on legacy harms the industry figures. This means that it continues to be a large ROA for the industry until it continues to be small in company value, the opposite continues to be a small ROA for the industry until it continues to be a large company value. 
Return on Assets (ROA) is a comparison of profitability which is shown by the analogy between the net profits obtained from the main activities of the industry and the total assets owned by the industry for carrying out industrial activities using totality and is claimed as a percentage. The research results prove that the ROA of the industry continues to increase until it continues to shrink in industry figures and reverse. This matter is caused by the ability of industrial management which is not yet able to manage the legacy owned by the industry efficiently and efficiently, as a result, the benefits are small, on the other hand, the legacy can be managed by large-category industries. This means that the budget spent for operations by the food and beverage sub-sector industry during the research period does not match the benefits obtained. This matter proves that many industrial budgets are idle, as a result, in conclusion, it can reduce industry expertise in obtaining profits.

If the company uses the entire budget for surgery to the maximum or according to the industry's wishes, the maximum benefits will be obtained. If the profits are large with investors owning the company's shares, the stock market price can increase and the number of companies will also increase. Therefore, the industry is obliged to use its inheritance to the maximum extent to protect the industrial figures so that they are always in a good situation. These results are in line with the research tried by (Irnawati, 2019), but contrary to the results of the research tried by (Oktrima, 2017).

\section{The Effect of Leverage on Firm Value}

Based on the results of the analysis, it can be seen that the $t$ value of the effect of leverage on firm value is -6.003 , the P-value is 0.000 , and the coefficient (beta) is -0.001 . With this, it can be concluded that leverage harms industry figures. This means that the leverage of the industry continues to increase until it continues to be small in company value, on the contrary, it continues to be small, the leverage of the company continues to increase the value of the company.

The leverage ratio is a financial comparison that measures industry expertise in fulfilling its long-term roles (long-term loan ) such as interest payments on debt, final major payments on debt, and other ongoing obligations. The ratio of leverage can be measured by equalizing the amount of debt and capital owned by the company. Leverage can be understood as an estimator of the effect attached to an industry. That is, the leverage that continues to become large proves the risk of investing that continues to be large as well. Companies with a ratio of leverage that is relatively small at risk leverage more generally small. With the high ratio of leverage, it proves that the industry is not solvable, which means that all debts can be said to be large compared to all of its assets. If a company is said to be not solvable, it will decrease the value of the company.

This is since investors view an industry with large assets but also a large leverage effect, so they want to make double assumptions to donate to that industry. Because it is feared that large assets could be obtained from debt which would increase investment risk if the industry cannot pay off its obligations on time. By continuing to increase the amount of debt used by the industry to assist industrial operations, they wanted to lower the PBV figure because the debt level was large and the burden guaranteed by the industry was also large. This result is in line with the research tried by (Dewi \& Abundanti, 2019) but contradicts the results of the research attempted by (Kadim \& Sunardi, 2019). 


\section{CONCLUSION}

Rooted in the data that has been combined with the results of testing that has been done on the case, until it can be concluded that the earnings opacity influence the direction of a negative relation to the company value. That is, the bigger the level of earnings opacity of the company, the smaller the value of the company. And conversely the lower the level of earnings opacity of the company, the bigger the value of the company. Tax Avoidance affects the direction of a negative relationship to Firm Value. This means that the bigger the level of corporate tax avoidance, the smaller the firm value. And conversely, the smaller the level of corporate tax avoidance, the bigger the firm value. For control variables where Price Earning Ratio (PER) affects the direction of a positive relationship to Firm Value. This means that the higher the company's price-earnings ratio, the higher the firm's value. On the other hand, the smaller the company's price-earnings ratio, the smaller the firm's value. Return on Assets (ROA) affects the direction of the negative relationship to Firm Value. This means that the higher the ROA level of the company, the lower the company value. And conversely, the lower the ROA level of the company, the higher the company value. Leverage affects the direction of the negative relationship to Firm Value. This means that the higher the level of corporate leverage, the lower the firm value. And vice versa, the lower the level of corporate leverage, the higher the firm value. Based on the data that has been collected and the results of testing that have addressed the problem, suggestions are obtained to increase the research company sector so that it represents the industrial sector on the Stock Exchange and it is expected to add more varied independent variables.

\section{REFRENCES}

Andriani, L. \& mayar afriyenti. (2019). Accrual quality moderates earnings opacity against the cost of equity . 1 (3), 1363-1375. https: //doi.org/10.24036/jea.v1i3.148

Apsari, L., \& Setiawan, PE (2018). The Effect of Tax Avoidance on Firm Value with Dividend Policy as a Moderation Variable. E-Journal of Accounting, 23, 1765. https://doi.org/10.24843/eja.2018.v23.i03.p06

Bhattacharya, U., Daouk, H., \& Welker, M. (2017). The World Price of Opacity (Vol. 78, Issue 3). The Accounting Review. https://doi.org/10.2139/ssrn.282117

Brigham and Housten. (2011). Fundamentals of Financial Management . Jakarta: Four Salemba :

Dewi, NPIK, \& Abundanti, N. (2019). The Influence of Leverage and Company Size as Mediation Variables. Management E-Journal , 8 (5), 3028-3056. https://doi.org/10 .24843 / EJMUNUD.2019.V08.I05.P16

Fadillah, H. (2019). The Effect of Tax Avoidance on Firm Value with Institutional Ownership as a Moderation Variable. JIAFE (Scientific Journal of Accounting, Faculty of Economics), 4 (1), 117-134. https://doi.org/10.34204/jiafe.v4i1.1082

Fahmi. (2012). Financial Statement Analysis (Print 2). Alfabeta

Frank, M. Margaret, Lynch, LJ, \& Rego, SO (2009). Tax Reporting Aggressiveness and Its Relations Financial Reporting University of Virginia. Accounting Revie , 84 (2), 467-496. https: / /dx.doi.org/10.2139/ssrn.647604

Ghazali. (2013). Applications Multivariate Analysis With SPSS Program (Keem Edition pat ). Semarang: Diponegoro University Publisher 
He, G., Ren, HM, \& Taffler, R. (2020). The impact of corporate tax avoidance on analyst coverage and forecasts. In Review of Quantitative Finance and Accounting, 54 ( 2). https://doi.org/10.1007/s11156-019-00795-7

Irnawati, J. (2019). The Effect of Return on Assets (Roa), Return on Equity (Roe) and Current Ratio (Cr) on Firm Value and Their Impact on Dividend Policy. SEKURITAS Journal (Stocks, Economics, Finance and Investment), $2 \quad 12$ (2), 1. https://doi.org/10.32493/skt.v2i2.2488

Jensen, C., \& Meckling, H. (1976). THEORY OF THE FIRM : MANAGERIAL BEHAVIOR, AGENCY COSTS AND OWNERSHIP STRUCTURE I. Introduction and summary In this paper WC draws on recent progress in the theory of (1) property rights, firm. In addition to tying together elements of the theory of e. Journal of Financial Economics, 3 (4), 305-360. https: //dx.doi.org/10.2139/ssrn.94043

Kadim, A., \& Sunardi, N. (2019). The Effect of Profitability, Firm Size on Leverage Implications on the Value of Cosmetics and Household Companies listed on the Indonesia Stock Exchange. SEKURITAS Journal (Stocks, Economics, Finance and Investment), 3 (1), 22. https://doi.org/10.32493/skt.v3i1.3270

Karimah, HN, \& Taufiq, E. (2016). The Effect of Tax Avoidance on Company Value. ECOMBIS REVIEW: Scientific Journal of Economics and Business, 4 (1), 72-86. https://doi.org/10.37676/ekombis.v4i1.156

Compass , (201 4 ). Coca-Cola Allegedly Cheating On Tax Payments. Retrieved January 15, 2021,fromhttps://ekonomi.kompas.com/read/2014/06/13/1135319/cocacola.diduga.akali.seto ran.pajak.

Kothari, SP, Leone, AJ, Simon, WE, \& Wasley, CE (2005). Performance Matched Discretionary Accrual Measures. Journal of Accounting Economics, 39 (1), 163-197. https: //doi.or g / 10.1016 / j / jacceco.2004.11.002

Kuncoro. (2013). Banking Management Theory and Applications. Yogyakarta: BPFE

Kushartono, RC, \& Nurhasanah, N. (2018). Analysis of the Effect of Financial Ratios on Firm Value in Companies Incorporated in the Lq45 Index 2010-2016 Period. Buana Ilmu, 2 (1), 108-125. https://doi.org/10.36805/bi.v2i1.278

Lasrya, E., \& Ningsih, O. (2020). Analysis of Factors Affecting Profit Persistence in Food and Beverage Companies Listed on the Indonesia Stock Exchange for the period 2013 - 2017. Research in Accounting Journal (RAJ), 1 (1), 16-31. https://doi.org/10.37385/raj.v1i1.31

Murkana, R., \& Putra, YM (2020). Analysis of Factors Affecting Tax Avoidance Practices in Manufacturing Companies in the Consumer Goods Industry Sector Listed on the Indonesia Stock Exchange 2015-2017. Profita Journal, $13 \quad$ (1), 43. https://doi.org/10.22441/profita.2020.v13.01.004

Oktrima, B. (2017). EFFECT OF PROFITABILITY, LIQUIDITY, AND CAPITAL STRUCTURE ON COMPANY VALUE (Empirical Study: PT. Mayora Indah, Tbk. Years 2011 - 2015). SEKURITAS Journal (Stocks, Economics, Finance and Investment), 1 (1), 98107. https: // dx .doi.org / 10.32493 / skt.v1.i1.622

Prastiwi, D., \& Walidah, AN (2020). The effect of tax aggressiveness on firm value: Moderating effects of transparency and institutional ownership. Journal of Economics and Business, 23 (2), 203-224. https://doi.org/10.24914/jeb.v23i2.2997 
Ray Ball, P. B. (1968). Ball_Brown_JAR_1968 . Journal of Accounting Research (JAR), 159178. http: //doi.org/10.2307/2490232

Ross, SA (1977). Determination of Financial Structure: the Incentive-Signaling Approach. Professor of Econoics and Finance , 8 (1), 23-40. https://doi.org/10.2307/3003485

Suripto, \& Sugiyanto. (2020). Company Transparency Moderates the Effect of Tax Avoidance and Leverage on the Value of Manufacturing Companies on the Indonesia Stock Exchange. Pamulang University Proceedings, 1 (1), 1-11. https : //doi.org/10.46306/rev.v1i1.10

Wang, F., Xu, S., Sun, J., \& Cullinan, CP (2020). Corporate Tax Avoidance: a Literature Review and Research Agenda. Journal of Economic Surveys, 34 (4), 793-811. https://doi.org/10.1111/joes. 12347

Warno, W., \& Fahmi, U. (2020). The Effect of Tax Avoidance and Agency Costs on Company Value with Audit Quality as a Moderation Variable in Lq45 Companies. EL Muhasaba Journal of Accounting, 11 (2), 188-201. https://doi.org/10.18860/em.v11i2.9225 